\title{
Path Choice of Targeted Poverty Alleviation in Universities of Applied Sciences
}

\author{
Wang Shuangming ${ }^{1,2}$ \\ ${ }^{1 .}$ Dean's Office, Xi'an Siyuan University \\ Xi'an, China \\ ${ }^{2}$ Malaysia University of Science and Technology \\ Kuala Lumpur, Malaysia \\ e-mail: 646422452@qq.com
}

\author{
Fu Shiqiu \\ College of Liberal Arts, Xi'an Siyuan University \\ Xi'an, China \\ e-mail: 137792522 @qq.com
}

\begin{abstract}
The path choice of targeted poverty alleviation in education is the key to ensure the performance and effectiveness of the targeted poverty alleviation in universities of applied sciences. According to the challenges that the universities of applied sciences face in their work of targeted poverty alleviation in education, we shall systematically advance the work by using information technology to build a poor-student identification system, using the advantages of universities to carry out poverty alleviation in education, improving the linkage mechanism for poverty alleviation in education, vigorously promoting the development of industry transformation and upgrading and implementing the poverty alleviation in education through combination of production and teaching, widely publicizing the cases of poverty alleviation in universities of applied sciences, etc.
\end{abstract}

Keywords-Component; Targeted Poverty Alleviation; Challenges; Path Choice; Applied Sciences; Universities

\section{INTRODUCTION}

As early as the inauguration of the United Nations in 1945, all member states unanimously agreed to include "poverty eradication" in the "UN Charter." However, after nearly a hundred years of hard work, poverty in various countries in the world still exists. As the largest developing country in the world, China also has the problem of poverty. The CPC and the Chinese Government have led the people of all ethnic groups across the country in doing a great deal of arduous work in eliminating poverty and have achieved tremendous achievements. From 2013 to 2016, a total of 55.64 million people were poverty-alleviating nationwide, with an average annual poverty reduction of 13.91 million[1].

General Secretary Xi Jinping pointed out in his report of the 19th National Congress of the Communist Party of China: "We must mobilize the whole Party, whole nation and all social forces and insist on targeted poverty alleviation and take targeted measures for poverty alleviation", "pay attention to the poverty alleviation combined with ambition promotion and education improvement" and "ensure that under the current poverty line in China, the rural poor population will be lifted out of poverty, all poverty-stricken counties will remove their labels on poverty and the overall regional poverty will be solved to achieve real poverty alleviation by 2020"[2]. In 2017, the year of deepening targeted poverty alleviation and taking targeted measures for poverty alleviation, Premier Li Keqiang emphasized in this year's Report on the Work of the Government: "We shall reduce the rural poverty population by more than 10 million this year "[3]. Education is the fundamental means of "ambition promotion" and "education improvement" and poverty alleviation in education is the fundamental way to block the intergenerational transmission of poverty. As a center for leading knowledge innovation, universities should play a prominent role in poverty alleviation through education.

\section{POVERTY ALLEVIATION IS THE MISSION OF UNIVERSITIES OF APPLIED SCIENCES}

Poverty alleviation through education aims to improve the quality of population in impoverished areas with the purpose of human development. The core means for this is education, and the key to it is intellectual resources[4]. Universities of applied sciences has a wealth of high-quality intellectual resources. Universities of applied sciences are an important part of higher education and are the backbone of the development of higher education. According to statistics, as of May 30, 2016, there are 2595 ordinary colleges and universities in China, of which 75 are directly under the Ministry of Education and 43 are directly under the national ministries and commissions. The rest are universities of applied sciences, accounting for the vast majority of ordinary colleges and universities nationwide[5]. A large number of teachers and students in universities of applied sciences are important educational-practice subjects for poverty alleviation.

Universities of applied sciences have a large amount of material resources. The material resources that universities and colleges own including the experimental equipment, teaching facilities and places provide the support for the poverty alleviation through education. The network resources owned by the schools have raised the efficiency of poverty alleviation through education. The school-running and educational experience based on local economic and industrial advantages is a key factor in the successful implementation of targeted poverty alleviation through education.

The Notice on Opinions for the Implementation of Poverty Alleviation Project Through Education clearly stipulates that colleges and universities directly under the Central Ministries (Commissions) are mainly involved in the targeted poverty alleviation in key counties for national 
poverty alleviation and development work. Provincial colleges and universities, in accordance with the unified arrangement of provincial people's governments, shall participate in the targeted poverty alleviation work within provincial administrative areas[6]. In this sense, poverty alleviation through education deserves to be the historic mission of universities of applied sciences, which helps to enhance the core competitiveness of the schools.

\section{CHALLENGES FACED BY UNIVERSITIES OF APPLIED SCIENCES IN TARGETED POVERTY ALLEVIATION}

\section{A. The precise identification of the poor students in universities of applied sciences needs to be strengthened}

The identification of poor students performed by universities of applied sciences is not accurate. At present, the universities that make identification of the poor students mainly relies on the unified registration form of family poverty issued by grassroots Office of Poverty Alleviation and Development. Students enrolled in universities of applied sciences can submit their students' registration forms of family poverty with a seal for confirmation from grassroots units where they are located, then the universities will apply for subsidies in line with relevant subsidy standard. In the process of actual identification, the information about the number of the real poor students in the poverty-stricken areas as well as the types of poverty among them, the causes of poverty, the ability to get out of poverty, the situation of receiving training and education and the appropriate assistance measures are inaccurate, and the poverty alleviation and assistance measures are too general, lacking pertinence, which affect the fairness of the poor students receiving education.

\section{B. The measures for targeted poverty alleviation in universities of applied sciences need to be improved}

So far, although the whole China have explored and constructed the "tuition assistance mode by combination of rewards, subsidies and loans" and "skills training mode by combination of long and short practice", the poverty alleviation and development gradually changes from the "blood transfusion" to "hematopoiesis". In the course of implementing poverty alleviation through education in universities of applied sciences, there are still problems like the lack of awareness of poverty alleviation among poor students, failure to combine various forms of poverty alleviation and development and lacking in accuracy on training content, training forms and employment assistance for the poor students. The key task for the universities of applied sciences is to comprehensively consider the problems and measures from the systematic, scientific and accurate aspects and further refine and improve the measures for targeted poverty alleviation through education.

\section{The effect of targeted poverty alleviation in universities of applied sciences needs to be advanced}

The goal of poverty alleviation in universities of applied sciences is to improve the quality of students so that they can get employed smoothly and start their own businesses to get out of poverty. To some extent, the education in universities of applied sciences is the type of education directly facing the labor market, which is most closely linked to the labor market. Therefore, universities of applied sciences should put the perspectiveness, guidance and practicality of education and training together. It is necessary to pay attention to organizing teaching contents in light of the local economic development level, and to instill advanced scientific and technological knowledge and labor skills so as to enhance students' adaptability. However, many universities of applied sciences employ vocational education and training without full investigation of the employment market. They only paid attention to the scale of education and neglected the employment situation. Many schools did not set up a corresponding employment information feedback mechanism for graduates. There is a lack of indepth knowledge of secondary employment and follow-up of students, resulting in a disconnection between school education and the labor market. The talent training quality does not meet the job requirements, which will seriously affect the employment of students, thus affecting the effectiveness of poverty alleviation through education.

\section{PATH CHOICE OF UNIVERSITIES OF APPLIED SCIENCES IN TARGETED POVERTY ALLEVIATION}

\section{A. Use information technology to build an accurate poor- student identification system}

Generally, poverty alleviation through education mainly relies on information collection of manually collected data, and then the measures for identification of the poor students will be developed through quantitative analysis. However, considering the living conditions of the poor students and the dynamic allocation of resources for poverty alleviation, it is difficult to accurately identify the poor students if they work in a static and backward manner. Through the information technology such as cloud computing and big data, the production and living conditions and resource allocation status of the poor students can be digitized and analyzed to assess the poverty level of them, so as to provide a decisionmaking reference for the accurate identification[7]. In the late stage of identification, the relevant departments, in order to ensure the precise positioning of the poor population, can disseminate the information of the poor students through the big data platform for poverty alleviation and encourage teachers and students to supervise the publicized results to ensure the accuracy and authenticity of poverty identification.

\section{B. Use advantages of universities to carry out poverty alleviation work through education}

Universities of applied sciences should take the exploration of a new mode of poverty alleviation for human resource development as a general guideline, continue to innovate poverty alleviation modes and methods, connect talents with construction of human resources, connect academic disciplines to special industries, and connect scientific and technological advantages and resource advantages. We can utilize advantages of universities to 
carry out poverty alleviation work through education through the targeted education and training.

Universities of applied sciences should carry out education poverty alleviation according to their own specialty and resource specialty. For example, the teachers and students majored in computer can carry out computer skills training, those majored in health care can carry out nursing training and those majored in law can carry out legal education training or legal advice.

Incentives and guarantee mechanisms for teachers to undertake compulsory education and training in poor areas should be further improved, such as giving certain subsidies and prioritizing promotion of titles under the same conditions, or increasing conditions for compulsory education in assessing professional titles. In addition, in order to improve the benefit of poverty alleviation through education, universities of applied sciences should rely on such predominant disciplines as communication science, pedagogy and education technology to establish a distance education platform jointly with enterprises or social organizations.

Universities of applied sciences should fully investigate the needs of local poor people and formulate practical and characteristic education and training programs such as agricultural production technology training for farmers, training for cadres, training for medical staff, training for principals or teachers. For urban migrant workers and other groups with high mobility, preferential measures can be allowed for them to go to the nearest university and work place to receive education and training.

\section{Improve the linkage mechanism of poverty alleviation through education}

In order to ensure the effective promotion of targeted poverty alleviation through education, we must establish a special regulatory agency for poverty alleviation management, strengthen the guidance and co-ordination of the same industry, and intensify the integration of poverty alleviation and development resources through vocational education at all levels in all industries and focus on the coordination of the allocation, use, supervision and evaluation of educational resources in universities of applied sciences [8]. We shall further optimize the allocation of educational resources for universities of applied sciences, clarify the job responsibilities, contents and requirements of various departments through further implementation of relevant policies and regulations such as the Vocational Education Law, refine the measures for work, step up implementation of anti-poverty work in vocational education, and speed up the introduction of relevant incentive measures, and establish a cooperative school-running mechanism in which industry and enterprises and various social resources are actively involved in jointly assuming a social responsibility to fight poverty. We shall reward the quality and quantity of units and individuals to complete the work of poverty alleviation and fully mobilize the enthusiasm of all relevant departments to participate in the work of poverty alleviation so as to form a concerted effort to effectively promote the work of targeted poverty alleviation through education.

\section{Vigorously promote the development of industry transformation and upgrading and implement poverty alleviation by the combination of production and teaching}

Universities of applied sciences are boosters for the development of local industries. The development of local industries requires a large number of skilled personnel, which provide opportunities for the poor students in need to find jobs and alleviate poverty. The implementation of targeted poverty alleviation through education in universities of applied sciences cannot be separated from the development of local industries. If there is no good industrial base, the education in universities of applied sciences will be like water without a source and a tree without roots. Therefore, in order to promote the targeted poverty alleviation through education in universities of applied sciences, we must vigorously promote development of local industry transformation and upgrading and provide opportunities for the poor students to get out of poverty through employment. Universities of applied sciences should aim at local leading industries and advantageous industries, and provide technical and skills training urgently needed in the labor market targeted at the poor to promote the poverty alleviation through combination of production and teaching. We shall provide more opportunities for employment and entrepreneurship for the poor and broaden the channels for eliminating poverty. Universities of applied sciences should adjust the major setup based on the demand for talents to ensure the relevance and practicality of personnel training and enhance the adaptability and competitiveness of personnel training.

\section{E. Strengthen the internal management reform of universities of applied sciences and improve the personnel training level}

To implement the targeted poverty alleviation through education, universities of applied sciences must improve the ability and level of targeted poverty alleviation. In the process of implementing targeted poverty alleviation through education, universities of applied sciences must achieve the accuracy of the poor identification, training contents, training forms, financing measures, employment assistance and follow-up and adjustment, so as to ensure the effect of targeted poverty alleviation through education[9]. This requires the universities of applied sciences to strengthen the internal management reform and improve the personnel training level. On the one hand, it is necessary to set up a mechanism for the cooperation in education among governments, schools and enterprises and formulate a charter for school-running through the establishment of a school council, so as to attract the head of industry enterprises to enter the school council, and thus making concerted efforts in school running of universities of applied sciences. On the other hand, we should step up the team construction of "double-certificated teachers" in universities of applied sciences and set up a system of selecting part-time teachers with the best backgrounds in the industries and enterprises. We shall gradually improve the system of training young 
teachers, reinforce the practice training of young teachers in the enterprises, and strengthen the cooperation with enterprises and industries to train a group of doublecertificated teachers.

Universities of applied sciences should reform the traditional mode of running a school (training) and set up a vocational education system that suits the individual needs of the poor. The system of flexible vocational education can be constructed through the establishment of credit banks, halftime work-study programs and other forms of education to mobilize the poor to receive vocational education through school-enterprise cooperation, combination of work and study, internship in positions, order training and new apprenticeships. Through the implementation of teaching methods such as project teaching, case teaching and work process orientation, the learning process and work process are organically integrated, so that the poor students who receive education in universities of applied sciences can bring their technology into the market and smoothly achieve employment.

\section{F. Widely publicize the poverty alleviation cases in universities of applied sciences}

General Secretary Xi Jinping attaches great importance to education for poverty alleviation and has repeatedly stressed the issue of "ambition promotion goes ahead of poverty alleviation." A successful case of poor families or their members receiving education and training to get rid of poverty can not only ignite the aspirations of poor families to get out of poverty, but also bring about a positive craze for education and training in the rural areas and even in the whole impoverished areas, which is just like "lighting a few to light up all". Public opinion departments at all levels should vigorously publicize the positive role of universities of applied sciences in the work of targeted poverty alleviation and raise the public's awareness of the importance of vocational education. Through various channels, we should publicize the cases of poverty alleviation via vocational education for the large number of poor people so that they can set up the concept of "getting rid of poverty" such as "skills change personal destiny", "skills improve production quality" and "skills improve quality of life". We shall delve deeper the live typical cases in "every profession produces its own topmost master" and publicize "various advantages in employment and multiple pathways to progress" in universities of applied sciences to guide the poor to overcome negative thoughts of "waiting, depending and asking for" and correctly understand the vocational education. Ideologically, we should let them build courage and ambition to get rid of poverty through learning technologies and improving skills and abilities. In their actions, we shall make them not only contribute to the economic and social development of the country and the region, but also raise the level of their personal income, achieve decent work and reach the goal of taking targeted measures for poverty alleviation.

\section{ACKNOWLEDGMENT}

On poverty alleviation through education, colleges and universities is the core and the talent is the key. The poverty alleviation through education in the final analysis is to raise the education level and quality of the population in the underdeveloped areas. The key to improving the education level and the quality of the population depends on talents. Universities of applied sciences are shouldering the heavy responsibility of training outstanding talents for localities. They should further enhance their ability to run schools, innovate their science and technology and serve the community.

[Subject] Projects of Social Science Foundation in Shaanxi in 2017: Research on Application of Big Data in Targeted Poverty Alleviation in Shaanxi Universities.

Education Department of Shaanxi on Scientific Research Program in 2018: Issues and Countermeasures on Targeted Poverty Alleviation Through Education in Old Revolutionary Base Areas in Northern Shaanxi.

\section{REFERENCES}

[1] [2]Hotspot in The 19th National Congress of the Communist Party of China, "Achieving Poverty Alleviation to Embrace an All-round Well-off Society", [EB/OL]. http://www.gov.cn/xinwen/201710/21/content_5233418.htm, October 28, 2017. (references)

[3] Li Keqiang, "Reducing the Rural Poverty Population by More Than 10 Million This Year',[EB/OL].

http://www.china.com.cn/lianghui/news/201703/05/content_40411476.htm, October 28, 2017.

[4] Dai Ruihua and Yu Xuan, "Targeted Poverty Alleviation Through Education: Difficult Positions and Governance Paths", [J]. Research in Educational Development, 37 $7^{\text {th }}$ ed., vol. 07, 2017: 9-15+30.

[5] Ministry of Education, People's Republic of China, "2016 List of National Institutions of Higher Education", [EB/OL]. http://www.moe.edu.cn/srcsite/A03/moe_634/201606/t20160603_248 263.html, October 28, 2017.

[6] General Office of the State Council, "Forwarding of the Notice on the Opinions of the Ministry of Education and other Departments on Implementing Education Poverty Alleviation Project by the General Office of the State Council", [EB/OL].

http://www.moe.gov.cn/publicfiles/business/htmlfiles/moe/moe_1779 /201309/157306. html, October 31, 2017.

[7] Chen Enlun and Chen Liang, "Model Exploration of Poverty Alleviation in Poor Areas from the Perspective of Educational Informatization", [J].China Educational Technology, vol.03: pp.58-62, 2017.

[8] Li Xiang, Zeng Yu and Song Pu, "Targeted Poverty Alleviation Through Education in Ethnic Areas: Innovations in Internal Mechanisms and Mechanisms", [J].Guangxi Social Sciences, vol.02: pp.201-206, 2017.

[9] Xu Mei, "Review and Development Path on Vocational Education in Rural Areas Based on the Targeted Poverty Alleviation", [J]. Education and Vocation, vol.18: pp.25-31, 2017. 